\title{
Cultivation of Microalgae Chlorella sp on Fresh Water and Waste Water of Tofu Industry
}

\author{
Widayat $^{1,2, *}$, John Philia $^{2}$ and Jessica Wibisono ${ }^{2}$ \\ ${ }^{1}$ Center of Biomass and Renewable Energy (C-BIORE) Center of Research and Service Unit Diponegoro University (CORES DU) \\ ${ }^{2}$ Department of Chemical Engineering, Faculty of Engineering, Diponegoro University
}

\begin{abstract}
Chlorella sp. is a microalgae that potential for food supplement, pharmaceuticals, animal feed, aqua culture and cosmetics. Chlorella sp. commonly growth in sea water. Indonesia as a producer of tofu generated more liquid waste. Nutrient that contained in the tofu wastewater are very useful for the production of microalgae. Cultivation carried out for 7 days at different percent volume of tofu liquid waste showed that the more volume of tofu liquid waste make them longer process decipherment of polymer compounds in the waste, that's make the growth rate of Chlorella sp. are slowness. Variable of $10 \% \mathrm{~V}$ has the fastest growth rate. While, $90 \% \mathrm{v} / \mathrm{v}$ variable has the highest concentration of algae. It shows that Chlorella sp. better to grows in tofu wastewater than seawater.
\end{abstract}

\section{Introduction}

Indonesia is one of the tofu producers that quite productive either home or industrial scale with a number of industry reached 84.000 business units. Data obtained from BPPT (Agency for the Assessment and Application of Technology ) showed that for every 80 $\mathrm{kg}$ tofu produced, $2610 \mathrm{~kg}$ waste produced [1]. It means every year, for about 240 million people in Indonesia, $5,7942 \times 10^{10} \mathrm{~kg}$ industrial tofu waste produced annually.

Gases commonly found in tofu waste are nitrogen $\left(\mathrm{N}_{2}\right)$, Oxygen $\left(\mathrm{O}_{2}\right)$, hydrogen sulfide $\left(\mathrm{H}_{2} \mathrm{~S}\right)$, ammonia $\left(\mathrm{NH}_{3}\right)$, carbon dioxide $\left(\mathrm{CO}_{2}\right)$ and methane $\left(\mathrm{CH}_{4}\right)$. The gases are derived from the decomposition of organic materials contained in tofu wastewater [2]. If the tofu wastewater is being discharged directly into the environment, there would be precipitation of organic substances in the water body, the process of decay, and growth of pathogenic microorganisms. To resolve the problem, there are methods that can be solved tofu wastewater as medium cultivation microalgae.

Tofu wastewater contains some organic materials. The protein in tofu wastewater occupies about $60 \%$ of all solid fractions. Through amino acids fermentation in anaerobic treatment process, protein can be degraded into various organic compounds [3], which some of them can be used either for macronutrient or micronutrient for the autotrophic organism, such as microalgae.

Nowadays, micro algae are consumed as food supplement, pharmaceuticals, animal feed, aquaculture and cosmetics[4]. Some microalgae are able to remove the pollutant and able to produce lipids [5-7]. A Microalgae Chlorella pyrenoidosa including, Scenedes musobliquus, Chlorella and Spirulina platensis, Minutissima [6,8-10]. That microalgae are able and effective to remove the pollutant in the waste, but have a low productivity, low lipid content and intolerant in extreme environment condition [8,11].

Chlorella sp. is the most cultivated eukaryotic green micro alga, as it is widely used as a health food and feed supplement. It contains proteins, carotenoids, lipids, immune stimulator compounds, polysaccharides, vitamins, antioxidants and minerals [12]. The culture medium has a direct influence on cellular growth, as well as on concentration of microalgae [13]. Chlorella sp. is usually cultured on the nutrient solution that simulates sea water composition, with the addition of B1 and B12 vitamins. Air is injected into this culture medium to furnish carbon dioxide as the only carbon source [14].

In previous studies on Chlorella sp. various methods have been adopted to increase growth rate using sea water (nutrient composition, $\mathrm{pH}$, light effect, temperature), but only a few studies on culture medium have been published. Because of this, then conducted research to know the growth rate and algae concentration on cultivation microalgae types of Chlorellasp. in medium tofu wastewater.

\section{Fundamental Theory}

Microalgae cultivation can be carried out with freshwater, seawater, water from estuaries, wastewater from agricultural, industrial operations and domestic wastewater [15]. Algae media refers to the solution or culture in which algae grow. All the media haveseveral

*Corresponding author: widayat@live.undip.ac.id 
components in common: sources of nitrogen (in the form of nitrate, nitrite and ammonia), phosphorus, vitamins and trace metals. However the specific types of these nutrients, their concentrations and ratios vary between the media. It is important to know which media is best for optimum growth of the algae [16]. Some research suggests that tofu wastewater contains some nutrients which are very useful for the production of microalgae. Tofu wastewater contains some organic materials which mostly consist of proteins and lipids about $40-60 \%$ (226.06 mg/L to $434.78 \mathrm{mg} / \mathrm{L})$ and other compound which are carbohydrate $(25 \%-50 \%)$, and fat $(10 \%)[17,18]$. The wastewater also contains nitrate and phosphate [17]. Nutrient that contained in the tofu wastewater are very useful for the production of Chlorella sp.

\section{Material and Method}

The material used in this research is tofu wastewater and are obtained from tofu home industry $\mathrm{n}$ Mrican village, inoculums of microalgae Chlorellasp. are obtained from BPAP Jepara that cultivated using seawater and fertilizer $\mathrm{NPK}, \mathrm{NaHCO}_{3}$ technical grade, B1 and B12 vitamin. Tools are used include flask, aerator, neon lights, spectrophotometer Optima SP 300, salinity meter and glassware.

Research begins with the preparation of materials of tofu wastewater. Waste is filtered to reduce the total solid and then without sterilization, directly mixed with freshwater according variable percent volume $(10 \%$; $30 \% ; 50 \%, 70 \%, 90 \%$ ) with added nutrition $30 \mathrm{ppm}$. Also add nutrition $30 \mathrm{ppm}$ to seawater and freshwater. Microalgae Chlorellasp.10\% V added to the flask containing media with lighting and aeration for 24 hours. Measurement of the optical density is done every day by the spectrophotometry method using a spectrophotometer Optima SP 300 at a wavelength 680 $\mathrm{nm}$.

\section{Result and Discussion}

\subsection{Effect of Tofu Liquid Waste Concentration to Optical Density}

Based on Figure 4.1 shows that optical density values of all the variables tend to rise at the beginning of cultivation, and then decline in the mid-and rise in later cultivation. Increase in Optical Density (OD) at the beginning of the cultivation is the effect of the process of homogenization between sea water and total suspended solids of liquid waste. Dilution of total suspended solids leads to increased concentrations of tofu liquid waste. So, the value of OD in media at the beginning for cultivation 1-4 days tends to rise. While the decline of OD in cultivation in the middle occur because chemical compounds of polymer components in the waste degradation into simple compounds. Tofu liquid waste containing polymer compounds of carbohydrate such as oligosaccharides, monosaccharide as well as containing other compounds such as proteins, amino acids, isoflavone, saponin, $\mathrm{P}, \mathrm{Ca}, \mathrm{Fe}$ and other nutrients [19].

Optical density is measurement of the level of turbidity or density of a solution, more concentrated a solution be values of optical density will be increased. Waste polymer compounds degradation proses resulted in reduced concentration.

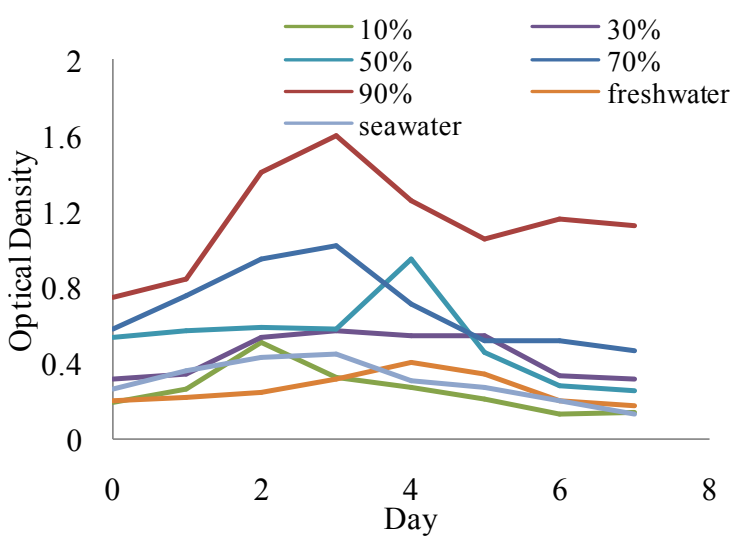

Fig.1. Relationship of optical density and $\%$ volume of tofu wastewater

Level decomposition of polymer compound on wastewater largely determines the growth rate of microalgae. Faster the polymer breaks down; it will be faster growth rate of Chlorella sp. anyway. Based on the Figure 4.1, fastest growth rates occurred at $10 \%$ volume that Optical Density had decrease on the third day. Variable more than $10 \%$ volume, polymer compounds decomposition takes a longer time so that less effective for the purpose of processing waste and biomass production. An addition of liquid waste is greater than $10 \%$ volume has a higher concentration of the polymer medium so that microalgae takes much longer for decomposition, that result slowness of the process of growth.

During the first four days of cultivation, the cells had better growth in tofu wastewater than in the freshwater or seawater. After four days, almost all variables reached stationary phase. Based on the figure 4.1 , the highest algae concentration occurred at $90 \%$ volume that had the highest Optical Density. The larger of percent volume tofu wastewater will be the highest concentration of algae production. Rapid growth in 10\% volume and high concentration of alga in $90 \%$ volume shows that Chlorella sp. usually grows in seawater, better to grows in tofu wastewater.

\subsection{Effect of Carbon Metabolism to Medium Salinity}

Based on figure 4.2, the salinity for almost of all variables is increased. Figure 4.3 shows that the biggest salinity increase occurred at $10 \%$ volume. High rates of growth and respiration need lot of energy, that obtained from carbon metabolism. Energy produced impact to evaporation of the culture medium, so, the salinity of the medium increases. 


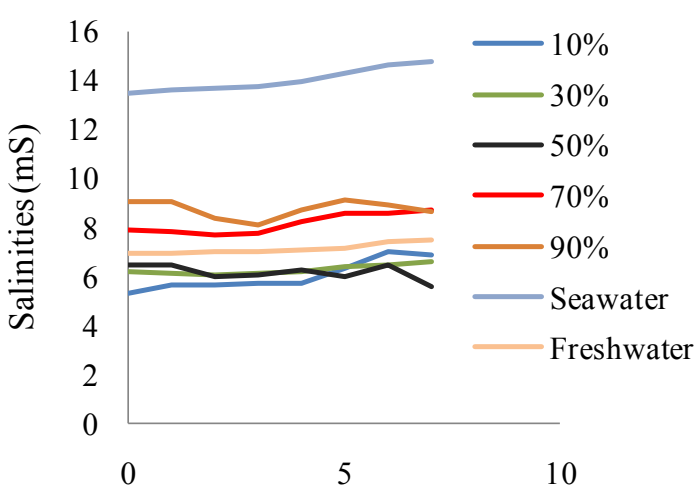

Fig.2.Time behaviour of salinity along Chlorella $s p$. cultivation

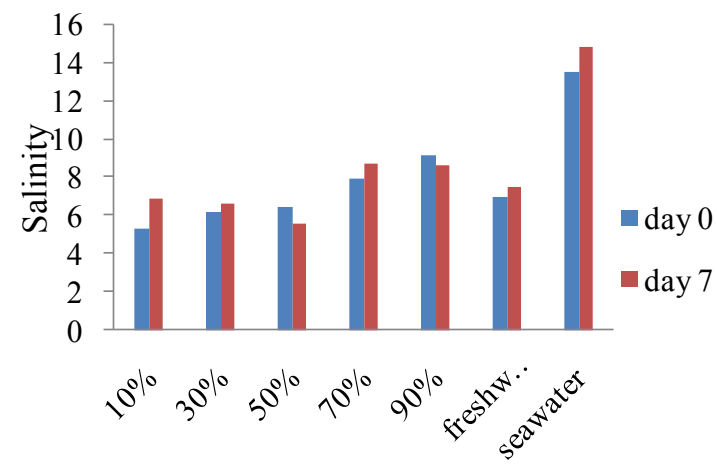

Fig.3. Ratio of salinity

\section{Conclusion}

Percent volume of tofu liquid waste effect on optical density. The larger of percent volume liquid waste will be the longer process decipherment of polymer compounds in effluent which resulted in the slowness of the process of growth of Chlorella sp. But, be increased in percent volume of liquid waste cause higher concentration of algae.

Rapid growth in $10 \%$ volume and high concentration of alga in $90 \%$ volume shows that Chlorella sp. uusually grows in seawater, able to grows in tofu wastewater. Algae growth and respiration need energy that obtained from carbon metabolism, it cause the salinity of the medium increases because of medium evaporation.

\section{References}

1. Herlambang A. Teknologi Pengolahan Limbah Cair Industri Tahu-Tempe. Teknologi Pengolahan Limbah Cair. Badan Pengkajian dan Penerapan Teknologi, Jakarta Pusat. 2002.

2. Kaswinarni, Fibria, Kajian Teknis Pengolahan Limbah Padat dan Cair Industri Tahu, Thesis (2007)

3. Ramsay IR and Pullammanappallil PC. Biodegradation. 2001;12:247-257.

4. Safi C, Areview. Renewable and Sustainable Energy Reviews. 2014;35,:265-278.

5. Garcia OP, Escalante FME, de-Bashan LE and Bashan Y. Water Research. 2011;45:11-36.

6. Bhatnagar A, Bhatnagar M, Chinnasamy S and Das KC. Applied Biochemistry and Biotechnology. 2010;161:523-536.

7. Li Y, Horsman M, Wu N, Lan CQ and Calero ND. Biotechnology Progress. 2008;24(4):815-820.

8. Hong Yang $\mathrm{S}$ and others. Bioresource Technology. 2011;102:9884-9890.

9. Martinez ME, Sànchez S, Jimènez JM, El Tousfi F and Munoz L. Scenedesmus obliquu. Bioresource Technology. 2000;73(3):263-272.

10. Yang CF, Ding ZY and Zhang KC. Microbiology Biotechnology. 2008;24:2919-2925.

11. Chisti Y.Biodiesel from microalgae. Biotechnology Advances. 2007; 25 (3):294-306.

12. Sharma R, Singh GP and Sharman VK. Effect of culture condition on growth and biochemical profile of Chlorella vulgaris. Plant Pathology and Microbiology. 2015;3(5).

13. Henrard AA and others. African Journal of Microbiology Research. 2015;9(21):1431-1439.

14. Frumento D and others. Biotechnology Progress. 2016;32(2):279-284.

15. Hadiyanto, Azimatun Nur, M.M. World Applied Sciences Journal. 2014., 31 (5): 959-967.

16. Idenyi JN, Ebenyi LN, Ogah O, Nwali BU and Ogbanshi ME. IOSR-JPBS. 2016;11(3):24-28.

17. Nurhasan and Pramudyanto. Penanganan Air Limbah Tahu. Yayasan BinaKarya, Jakarta Selatan. 1991.

18. Singh $\mathrm{J}$ and $\mathrm{Gu}$ S.Renewable and Sustainable Energy Reviews. 2010;14(9):2596-2610.

19. Barbosa ACL, Lajolo FM and Genovese MI. Food Chemistry. 2006;98(4):757-766. 